Title: Working Against the Odds: How probation practitioners can support desistance in young adult offenders.

Mr Pete Judd, Probation Officer

Dr Sarah Lewis, Senior Lecturer at the Institute of Criminal Justice Studies, University of Portsmouth.

\begin{abstract}
This paper seeks to explore how probation practitioners may work with young adult offenders (YAOs) to assist them in moving away from crime, by considering how a more desistance and relational focused approach may provide a number of alternative practices that could benefit YAOs. This discussion is formulated on both theoretical and applied grounds, with both authors having experience of working with YAOs, within a probation context in England. Whilst acknowledging that there are numerous ways in which a practitioner can assist an individual with their journey away from crime, this paper considers some of these ways, outlining potential challenges.
\end{abstract}

Keywords: young adult offenders, desistance, probation, relationships

This paper will turn to the desistance literature and examine its application with respect to working with young adult offenders (YAOs), within a probation context. It is proposed that relational work is central within this context and in light of the importance of relationships when working with YAOs, it will argue for a re-evaluation of the assessment and planning processes that take place with YAOs during their Community Orders (COs). It will explore 
how practitioners can build and safeguard their working relationships with YAOs and introduce the notion of ruptures as a way to illicit change and support desistance. It is not the aim of this article to create a set of prescribed standards of practice, as it is argued that each YAO may be responsive to many different approaches, which the creative practitioner would need to utilise during a $\mathrm{CO}$. For us, there is a need to create individualised opportunities relating to both the practitioner and offender through relational work, which recognises that success may be configured differently, when considering YAOs and their pathway out of crime. More so, this paper challenges current practice, from a micro relational level to a macro organisational perspective, proposing alternatives ways that aim to develop a more desistance and relational-focused service. It concludes by recognising the challenges that exist when working with YAOs, but actively encourages practitioners to invest and preserve their hope in change, to facilitate desistance in spite of these difficulties.

\section{Working with Young Adult Offenders}

Initially, it is important to acknowledge some of the unique challenges and contributions that YAOs bring to the table, when considering their journey away from crime. It has been personally observed that many colleagues are hesitant in working with YAOs, because they are characterised as living chaotic lives and may need intensive support (Barrow Cadbury Trust, 2005). And yet, both authors reflect that having worked with such a 'group' brings great reward for many reasons, including the general disposition of YAO's being, what Farringon, Loeber and Howell (2012) see as a changeable, redeemable and malleable population.

Although not identified as a distinct group within law (Prior, Farrow, Hughes, Kelly, Manders, White, \& Wilkinson, 2011), the Ministry of Justice (2012a) define a YAO as any 
offender aged between 18 and 20 andat 21, an offender is considered to be fully adult (Losel, Bottoms \& Farrington, 2012). Within the criminal justice system (CJS), YAOs are overrepresented and constitute a third of the probation service caseload, despite the finding that they form only $10 \%$ of the UK population (House of Commons Hansard, cited by Transition to Adulthood (T2A), 2012). Farrington et al (2012) highlight that the youth justice system (working with children and young people under the age of 18) focus on rehabilitation, whereas the adult system attends to more retributive punishment. Youth Justice Boards oversee the youth justice system in England and Wales and their approach, alongside interventions implemented by Youth Offending Teams (YOTs), have contributed to a recent fall of $39 \%$ in the number of children entering the youth justice system and a $25 \%$ reduction in the number sentenced to custody (Prison Reform Trust, 2012). The Prison Reform Trust (2012) go on to recommend that the remit of YOTs should be expanded to incorporate 18-20 year olds to address their complex needs through; a more effective multi-agency approach; diversions away from custody and; the introduction of more robust community sentences that are tailored to the specific needs of the individual. Whilst these findings may show positive developments, the rates of recidivism for this age group are still significantly high as $58 \%$ of YAO's released from custody in the first quarter of 2008 were reconvicted within 12 months (Prison Reform Trust, 2013). Therefore, attention needs to be paid to delivering sustainable and effective services, which support desistance and reduce risk of re-offending in the long term. These possible changes have a number of implications for probation and a possible widening of the net when addressing recidivism in the community. With a significant proportion of the adult probation service caseload being re-allocated to the private sector through the Transforming Rehabilitation agenda (Ministry of Justice (MoJ), 2013), more change could be on the horizon if these recommendations are implemented. Therefore, Considering the importance of relationships at all levels of the 'system' is important as role 
clarity becomes increasingly muddied and relationships are re-configured within a more competitive climate.

\section{Desistance and Young Adult Offenders}

Desistance among YAOs is a topic closely linked to the age-crime curve (Bottoms and Shapland, 2011). In England and Wales, Farrall (2002) suggests that the ages 17-19 for males, and 14-18 for females are the peak in criminal convictions before there is a decline. Whilst not all individuals follow the same trajectory over their lifetime, such a curve suggests that the CJS could be instrumental in either promoting or hindering the move towards desistance for YAOs (Shapland, Bottoms \& Muir, 2012). Carlen (2013) challenges the notion of rehabilitation and argues that some offenders may not have been habilitated initially due to contextual factors such as social disadvantage, highlighting the possibility that YAOs are at the start of their offending 'career' and may in fact be in the process of de-habilitation, rather than rehabilitation. How then, probation respond to this position is of great significance.

Farrall, Mawby and Worrall (2007) highlight that defining and operationalising desistance, like many other topics within social sciences, is not straightforward. Despite this, desistance within criminology is widely accepted as being associated with non-offending (Weaver \& McNeill, 2010), and is defined by Weaver and McNeill (2007a, p.90) as; "the process by which people come to cease and sustain cessation of offending behaviour, with or without intervention by criminal justice agencies”. Bushway, Piquero, Broidy and Cauffman (2001) note that desistance is therefore not a standalone event, but a process whereby an offender makes the decision to stop offending and refrains from further offending for an extended period of time. Indeed, Glaser (1969) highlights that the pathway away from offending is more of a "zigzag" process, as an offender may move from non-offending to offending in a 
“too-ing and fro-ing” manner (McNeill, Anderson, Colvin, Overy, Sparks \& Tett, 2011, p.4). This sequence may be repeated several times with the shift sometimes lasting for long durations and others being short lived. Whilst Gotfredson and Hirschi (1990) suggest that some offenders spontaneously desist without any explanation or intervention, for others, intervention may assist them in the process (King, 2013).

Attempts have been made to divide the process of desistance into two distinct stages, referring to 'primary desistance' and 'secondary desistance' (Maruna \& Farrall, 2004). 'Primary desistance' is the term used to recognise a crime-free gap or break in an offender's criminal career, with the maintenance of an offending identity (Maruna, Immarigeon \& LeBel, 2004). In 'secondary desistance', crime not only ceases, but offenders move away from their offending identity and begin to perceive themselves as a law-abiding citizen, or a “changed" person (Weaver \& McNeill, 2007b). Gadd and Farrall (2004) argue that although offending may appear to cease, it is unclear whether individuals actually stop offending, avoid detection, or, in the example of domestic abuse, physical violence may be replaced with controlling behaviour, of which only a small minority is classed as criminal under law.

With respect to assisting desistance, Burnett and McNeill (2005) and Bottoms, Shapland, Costello, Holmes and Muir (2004) state that it is not just capacity building or skills development that are important, but the offender's 'narrative' around how they construct or re-construct their identity. Maruna (2001) acknowledges that offenders need to develop a pro-social identity for themselves and essentially leave behind "past social and personal difficulties" (Wright, Carter \& Cullen, 2005, p.55) moving on to more positive opportunities and future chances of success (Maruna \& Roy, 2007). This process is described by Maruna (2001) as 'knifing off' the past from the current self and involves both internal and external 
changes (Kazemian \& Farrington, 2010). It is therefore recognised that desistance needs to be prompted and supported by both strong social networks and an individual's determination to change (Kazemian \& Farrington, 2010). This may be particularly difficult for YAOs, who may at this stage of their lives, be forming and building bonds as they are constructing their own identities as an adult. Whilst Maruna (2001) proposes the process of 'knifing off' the past, YAOs may in fact be creating anti-social bonds that will sustain their criminality for some time.

Although the mobilization of human capital including attitudes and beliefs, values, motivation and decision making are important in the process of desistance (Burnett \& McNeill, 2005), current accredited programmes were criticised for not taking into account the offenders' social/cultural environment, which may contribute to their offending (Shaw \& Hannah-Mofatt, 2004). Evidence within desistance research suggests that the mobilization of social capital (Burnett \& McNeill, 2005), around ties to family, employment and education are significant in explaining changes in criminal behaviour (Weaver \& McNeill, 2007b). Farrall (2002) found that meaningful employment and family formation were two aspects within an offender's social context, which have a significant impact on the desistance process. YAOs are however often restricted by structural constraints, notably in relation to their opportunities for further education and employment (Barry, 2012). With respect to their position on the age-crime curve, it can be suggested that generally speaking, desistance for a YAO is challenging at best.

Arguably the aim of probation is to help facilitate change and to encourage 'secondary desistance' (McNeill, 2006). This helps to achieve the key roles of offender management which are; public protection, offender rehabilitation and crime reduction(NOMS, 2006). 
With this in mind, fully establishing the role of the practitioner as an agent of change, needs greater and careful attention, as YAOs may metaphorically see their path more like a maze than a "zig zag" path. One author notes that a 'desister' once reflected upon his route out of crime, describing cycles of offending as he recalled thoughts such as "I have been here before" or "here we go again" and likening it to the kneading of dough. This highlights the particular challenge for practitioners as YAOs may indeed be gaining momentum with their offending, rather than de-accelerating. However, practitioners are reminded by Maruna's (2001) optimism that is shared by the authors, proposing that in spite of this, individuals can and do manage to gain a sense of agency and successfully move away from crime. The extent to which practitioners can influence this may seem of little significance, but could in fact inch a YAO forward towards desistance or contribute to a defining 'turning point' for that individual.

\section{Building positive working relationships with Young Adult Offenders}

Nacro (2013) highlighted the importance of sustaining the motivation of YAOs in the community by building positive working relationships. It is accepted that the relationship between probation practitioner and offender plays an integral part in the desistance process and should be at the centre of offender management (McNeill, 2003; Burnett \& McNeill, 2005). Since the introduction of 'What Works' and the effective practice principles, the traditional model of supervision in which the relationship was central, partially broke down (Robinson, 2005). Smith (2004) proposed that effective practice was concerned with the content of the intervention as a measure of success or failure, rather than the relationship between practitioner and offender. Matthew and Hubbard (2007) and Lewis (2014ab) propose that relational work is not considered deeply or critically enough within practice with respect to how relationships are formed, sustained and ended over the course of a CO. 
Therefore, the challenge as it sits today is not only continuing to promote the re-instatement of relational work, but also, re-configuring how it is addressed through a more analytical and reflexive stance, within a context that is becoming increasingly punitive (Matthews \& Hubbard, 2007).

When exploring the psychotherapeutic literature around relationships that promote change, Bordin's Triad (1994) highlights that within a therapeutic relationship, three components need to be established; (a) an agreement on "goals", (b) an agreement on "tasks" and; (c) a "bond" that nurtures a trusting relationship. This can be closely linked to Rogerian theory (1967) that considers the need to hold respect for an individual, express unconditional positive regard towards them and possess congruence between what a practitioner thinks, feels and behaves. From considering these two significant developments, there are mechanisms within probation practice that can allow for such aspects to be developed. Firstly, a collaborative designed sentence plan can be developed to fulfil two of the three components of Bordin's Triad (1994) and supervision can be a site in which this can be facilitated. The remaining features of the therapeutic relationship require the motivation of the practitioner, values that promote the possibility that transformative behaviour is possible and well developed communicative and reflective skills, to assist the practitioner in expressing themselves and engaging an offender in mutual sharing. Trust and respect are highlighted as being particularly valuable in building relationships with YAOs (Mason \& Prior, 2008). Self disclosure is recognised as one process that can be used to build trust, empathy and genuineness into the relationship (Offermann \& Rosh, 2012; Matthews \& Hubbard, 2007) and is also believed to narrow the gap between the practitioner and offender, highlighting a more humanistic view of the practitioner (Hopkinson \& Rex, 2003). 
It has more recently been suggested by Safran and Muran (2003) that relationships deepen through the survival of ruptures. Ruptures can be defined as temporary tears within the relationship that if repaired, can provide opportunities for learning. Considering this within the context of YAOs, the nature and frequency of ruptures (and the response to them) may hold great significance with respect to developing and sustaining positive relationships and engaging the YAO with their practitioner and order. Orsi, LaFortune and Brochu (2010) concluded from their work that an alliance is more difficult to establish with a young person, as they may be in conflict with others (i.e. parents) around ideas of offender change. Little work has been carried out relating to therapeutic relationships and YAOs, but from Shirk and Karver's (2003) work, it would indicate that relationships operate differently with younger people, when compared with adults. They found that the relationship at the latter stages of treatment were more predictive of treatment outcomes, rather than at the early stages (as seen with adult populations-See Castonguay, Constantino and Holtforth, 2006). Shirk and Kraver (2003) also noted that when examining Bordin's Triad, adolescents placed less emphasis on "goal" compared to the adult sample. This work was supported by Amaro, Blake, Schwartz and Flinchbaugh's (2001) work, which highlighted that young girls valued an emotional exchange within therapeutic relationships and Everall and Paulson (2002) stated that young people were more responsive to practitioners who presented themselves as allies, rather than people in authority. This signifies the importance of focusing upon relationships more mindfully in practice, recognising that YAOs may develop relationship differently, but more importantly, embracing the need to develop individualised theories with a YAO through listening, adopting a genuine and understanding position and acknowledging that ruptures are inevitable. Research would infer that ruptures take place for a myriad of reasons and exploring these tears in supervision may contribute to important lessons about relationships, 
which can be used in other aspects of the YAO's life. Roger's (1951) highlights that using the technique of self disclosure can lead to practitioners feeling vulnerable, talking about mistakes or feelings of discomfort within a relational context may also be very difficult. It is therefore recognised, that in order for relational mistakes to be verbalised and resolved effectively, top-down support needs to be in place to ensure that the practitioner feels that they can discuss relational problems openly.

In 2010, NOMS established the Offender Engagement Programme (OEP), which acknowledged that offending can be reduced through effective one-to-one engagement. The OEP developed the Skills for Effective Engagement Development and Supervision (SEEDS) programme, which offers a model of offender engagement and practice skills development for practitioners to encourage desistance amongst offenders. Within this framework there were six key themes; relationship building, motivational interviewing (MI), Pro-Social Modelling (PSM), structuring sessions, CBT, and Risk, Need and Responsivity (RNR) (see Sorsby et al, 2013). Whilst this framework embraces grounded research relevant to relationship development, it is argued that a relational foundation needs to be deepened, through a development of the practitioner's virtues and approach, to ensure that such techniques are presented as genuine and legitimate to the offender. It is therefore suggested that the SEEDS is developed further and fully utilises opportunities for practitioners to discuss the difficult relationships they experience with offenders, drawing on peer and organisational support to have time to explore relationships within a safe environment.

Building trust within the relationship has been shown to remove barriers towards promoting pro-social attitudes and behaviour within individuals (Brodie et al., 2009). Trotter (2009) recommends that the practitioner should model pro-social attitudes and behaviours with 
individuals, as such techniques have been found to reduce arrest incidents among YAOs (Trotter, 2009). PSM requires the practitioner to display behaviour that they expect of others, or in this case, offenders. This includes keeping appointments, being punctual, honest and reliable, respecting others and following up on tasks they have elected to do (Trotter, 2009). This does however, make assumptions around the practitioner adopting these expectations personally and having a respectful, reliable and honest approach to their work. Having explored ruptures within a probation context, the practitioner may not fulfil such behaviours and this could contribute to a tear in the relationship. Whilst some ruptures may be avoided due to time management skills and communication training (for example), ruptures are also inevitable within any relationship. It is argued that as well as striving to reduce such practices through guidance and training, setting realistic expectations that are responsive to both the practitioner and offender and equipping practitioners with ways in which they can resolve ruptures, may hold real value.

Hughes' (2012) research within probation observed that tensions do exist between building positive relationships with offenders and completing work to meet organisational requirements in relation to risk, and to ensure defensibility. Meeting the needs of the offender, organisation and practitioner can be incredibly challenging and a consideration of where relational work can be incorporated and developed into practice, in light of current structures may be a starting point. Relationships do not only engage the offender and build legitimacy, but can assist in informing continuous risk assessments, which is an important element of effective risk management (MoJ, 2007). Lewis (2014a) found that positive working relationships encourage offenders to be more honest with their practitioner and open up about problems that they are experiencing in their life. Further to this, Lewis (2014a) highlighted that negative working relationships can reduce offender communication and may 
in fact push them away from desistance or de-habilitate offenders. This may be particularly detrimental for a YAO, who may be falling deeper into criminality. It is therefore suggested that by focusing upon the relationship between the practitioner and YAO, important organisational needs will follow along with other rewards.

\section{Building relationships to assist in assessment and planning: The issue of maturity}

At present, approximately a third of people sentenced to custody each year are aged between 18 and 24 (House of Commons Hansard, cited by T2A, 2012), the T2A Allianc thereforeproposes that the variability of maturity can account for the different penological responses that underpin sentencing (T2A, 2013). Prior et al. (2011) found that physical maturity is generally completed by age 12 or 13 , whereas intellectual maturity, deals with key competencies, including impulse control, planning, reasoning, thinking before acting, emotional interpretation, abstract thinking, resistance to peer influence(s) and the ability to delay gratification (Farrington et al., 2012). Maturity is therefore something which must be considered on an individual basis and is significant and relevant to criminal justice professionals working with 18-24 year olds (Marder, 2013). For this reason, the Barrow Cadbury Trust (2005) and Farrington et al (2012) argue that special legal provisions for YAOs aged 18 to 24 should be introduced, which take into account levels of maturity and malleability. This can have profound implications, not just in terms of sentencing, but when considering that breaching court orders and police bail are often linked to age and level of maturity (Barrow Cadbury Trust, 2005). This would seem logical based on the possible chaotic lives of YAOs and one of the reasons why probation, as a service, may consider that they are working 'against the odds' when working with this 'group' of offenders. 
Maruna and Immarigeon (2004) proposed three principles of desistance; maturational reform, social bond theory and identity transformation. Maturational reform is the explanation offered for having stopped offending in relation to age and level of maturity. In England and Wales, the offender assessment tool OASys (Offender Assessment System) is a thirdgeneration risk-need instrument (Bonta and Andrews, 2010), which has the partial means of assessing maturity in offenders. However, Prior et al (2011) deemed this assessment to be largely based on professional judgement and brings with it issues of inconsistency. In many European countries including Belgium, Denmark and Germany, youth measures and sanctions can be applied to offenders over the age of 18 (Dunkel \& Pruin, 2012), and there have been calls for similar measures in Europe to be applied in England and Wales to cover YAOs up to the age of 24 (Barrow Cadbury Trust, 2005). These measures would potentially lead to YAOs being diverted away from custody and into community based sentences (Losel et al., 2012), which Allen (2008) suggests are more effective at reducing reoffending and promoting desistance. This alternative is supported by research findings, which suggest that labelling a young person as a 'criminal' may in fact increase their propensity to adopt a more criminal identity, nurturing the formation of an offenders "master status" (See Chiricos, Barrick, Bales \& Bontrager, 2007). Whilst desistance may involve the process of shedding old labels, this would indicate that systemic labels are being newly applied to the YAO to reinforce their criminal identity. Creating a more tolerant response becomes particularly difficult due to the role of the media within England and Wales and its demonising effects of YAOs as well as the focus upon punitive populism. In this sense, contradictions lie between supporting the YAO to desist and promoting 'tough' punishment to seemingly win votes.

The first contact many YAOs have with probation in England and Wales is at the presentence stage, when reports are prepared to inform the court of possible sentencing options. 
The Barrow Cadbury Trust (2005) cite in their report; Lost in Transition (2005), that sentencers should be more mindful of the maturity of YAOs and that assessments should be provided by specially trained officers from probation. Despite these recommendations, assessments in relation to maturity are not currently undertaken by probation. This may be due to the difficulties of 'measuring' maturity, as the concept in itself is ambiguous and this could pose problems for criminal justice practitioners (Farrow \& Hughes, 2013). In 2011, the Sentencing Council for England and Wales published the Assault Definitive Guidelines, which took account of an offender's level of maturity (2011). This was the first time the concept of maturity had been considered when sentencing adults and has subsequently been added to the sentencing guidelines for burglary and drug offences (T2A, 2012). By assessing maturity in addition to information gathered during the pre-sentence interview, more informed decisions in relation to the assessment, planning and implementation of interventions may follow. However, many pre-sentence reports are based on one meeting with the YAO, with practitioners being allocated increasingly less periods of time to substantiate and validate information. Whilst guidance has been provided regarding maturity, it has been observed by the authors that this is invariably not actively disseminated by topdown structures (or actively pursued by practitioners) and thus, tacit knowledge is relied upon as a norm. Whilst practitioners should be encouraged to use such knowledge to contribute to their judgements, it is also argued that this can either help or hinder an assessment, depending upon a number of variables, including the practitioner's previous biases either around offences or a specific YAO (See Day \& Ward, 2010). Canton (2011) acknowledges that practitioner's attitudes can impact on their work and Eidelson (2013) highlights that generalisations about an offender are commonplace and inevitable. Heylar-Cardwell (2009) therefore recommends the use of a maturity assessment instrument by probation at presentence stage, which may ameliorate some issues of subjectivity in assessing maturity. The 
implementation of the Taking Account of Maturity: A Guide for Probation Practitioners (T2A, 2013) could assist practitioners in identifying significant indicators around levels of maturity when completing OASys assessments. By understanding how maturity impacts on offending behaviour, it is hoped that probation can respond more effectively in facilitating the design of individually tailored assessments and interventions. This knowledge may inform the practitioner when assessing the risk of an individual and assist them in creating a meaningful sentence plan that addressed their needs, resources and goals and allows Bordin's Triad to be achieved through establishing a positive working relationship.

Gaining knowledge relating in a YAO's level of maturity may not be the only knowledge that a positive relationship can facilitate through open and honest communication. For example, when considering what the offender brings to the practitioner-offender relationship, Ansbro (2008) refers to Bowlby's (1944) work on attachment, which implies that the interactions between children and their care givers provide 'working models,' consisting of beliefs about self, others and relationships. Barry (2006) highlights the significance of the YAO's attachments with pro-social groups or individuals, acknowledging that these can promote desistance amongst YAOs. Research seems to indicate that children that have suffered abuse at the hands of their parents will themselves tend to develop a disorganised attachment style, which is associated with negative long-term consequences for children including dysfunctional emotional development, aggressiveness and poor peer relationships (ReitzelJaffe \& Wolfe, 2001). Farrall (2004) suggests that reuniting with family members that have a positive influence and developing new attachments to social groups, can lead to positive life changes. Therefore, an appreciation of past attachments need to be explored and understood by the practitioner, with the YAO, as this will form the basis for how the YAO interacts with 
the practitioner and shine a light on why the offender may react negatively within some relational contexts.

Setting the offender to one side, practitioners also need to be attended to. Practitioners also hold particular attachment styles, relational models and specific attitudes and values that contribute to how they interact with offenders. In the same tone that McNeill (2014) highlights the need for offenders to build on opportunities, motivation and capacity, practitioners also need to reflect upon how motivated they are in working with YAOs, what opportunities they are providing the offender to build a relationship (i.e. how receptive they are) and how capable they are in doing this. Whilst some relational skills can be taught and techniques can be utilised (such as motivational interviewing and pro-social modelling), there are qualities and virtues that make up the individual practitioner, which constitute their disposition and personality. This has implications with respect to recruiting the right people into probation work or to coin the phrase, getting "the right people on the boat". By examining relationships on a micro-level and developing relational theories that are formulated between the practitioner and offender, it is hoped that this would improve offender buy-in, increase relational connectivity and promote the development of a relationship that can facilitate change.

The introduction of 'What Works' and the principles of Risk, Need and Responsivity (RNR) brought about the creation of standardised assessments. This has led to more consistent risk assessments and the identification of appropriate interventions to reduce re-offending (Ward, 2010). The use of the risk/need approach is criticised for not acknowledging differences in risk/needs and having a tendency to see the worst in people (Hedderman, 2004). McNeill 
(2006, p.56) argues that within a desistance paradigm the assessment process should be; "an explicit dialogue and negotiation, assessing risks, needs, strengths and resources and offering opportunities to make good". Therefore, it is important to recognise and understand how an individual's previous experiences have helped to shape later life decisions (Laub \& Sampson, 2003). Whilst Fitzgibbon (2008) states that previous assessments give a good insight into previous behaviour and assist in making a complete assessment, the reasons for previous noncompliance may be an indicator as to whether a YAO is not engaging, due to intrinsic factors linked to personal development, maturity or more situational reasons.

McNeill (2003) highlights the importance of personal histories and current social circumstances in creating an individualised assessment and plan to aid desistance. However this is inherently difficult to achieve within current probation practice due to target-driven practice in relation to the completion of initial assessments. In April 2011, the National Offender Management Service (NOMS) introduced the Practice Framework - National Standards for the Management of Offenders for England and Wales. The framework relaxed the previous National Standards and reintroduced professional judgement and discretion in working with offenders (NOMS, 2011). The previous fifteen working day timeliness target (quality indicator) for completion of initial assessments and sentence plans was still present in relation to offenders assessed as high or very high risk of serious harm. For all other offenders the assessments needed to be completed in 'sufficient time' (NOMS, 2011). The term 'sufficient time' is open to interpretation, however it has been observed that local guidance determines local targets, as additional controls have been implemented because of concerns that assessments were not being completed. To add to the confusion, YAOs often live disorderly lives, which they struggle to make sense of (Maruna, 2001). This then makes it difficult to fully understand underlying problems that may have led to particular 
behaviours, thus making effective sentence planning difficult to achieve within a limited timeframe. An Ansbro (2008) recoginises that spending time developing a relationship with an offender is time well spent, but once again the odds are against the practitioner due to organisational pressure and restrictions.

With respect to sentence planning, the National Offender Management Model (NOMS, 2006, p.21) states that; "the scope of the plan should span the whole anticipated period of engagement, not just the current phase of it". If this is to be achieved with YAOs, then it is essential that a correct assessment of an offender's life history takes place in the first instance, as the anticipated period of engagement with probation could far exceed one $\mathrm{CO}$, due to our understanding of life-course criminality. Motivation is pivotal to desistance from offending (Farrall, 2002), however it is one element within OASys that is only briefly assessed, yet it is important in determining the structure and content of interventions (Lancaster \& Lumb, 2006). It is therefore urged that time is invested during the assessment stage to not only build rapport with the YAO, but to create a meaningful assessment that can effectively inform a collaborative sentence plan. Time to build legitimacy and explore the underlying reasons behind any previous non-compliance is needed, with an appreciation that previous assessments capture a moment in time and are written through the subjective lens of previous professionals. This is not to discredit prior assessment, but to fully acknowledge that the YAO is on a life-course trajectory and their situational and motivational position can alter.

Creating a sentence plan that is desistance-focussed is an important stage of the assessment process for a YAO and depending on how maturational reform, social bonds and narrative theory are interacting together will determine the type of plan that is to be implemented 
(McNeill, 2003). Within this framework the sentence plan needs to be formulated to address any legal requirements of the order (NOMS, 2006) and NOMS (2012) state that priority needs to be given to objectives aimed at addressing risks/needs linked to Risk of Serious Harm and risk of re-offending. During sentence planning, gaining employment is shown to have brought about dramatic changes in the lives of some YAOs (Farrall, 2004), by giving them meaningful structured routines (Laub and Sampson, 2003) and less time to associate with negative peers (Laub \& Sampson, 2001). Effective practice states that interventions are more effective if they are multi-modal, tackling a variety of offender (criminogenic) needs (McGuire \& Priestley, 1995). Lipsey's research (1995) found that a programme of interventions that includes both training or practical skills and psychological orientated interventions, such as cognitive behavioural techniques (CBT), are more effective at addressing offending behaviour amongst YAOs. Although a multi-modal approach to interventions has been shown to be more effective in reducing reoffending, it is our opinion that this type of approach may not be appropriate at the start of an order and that time to develop a therapeutic relationship is of great value in developing honest communication, trust and rapport as well as gaining knowledge of the YAO to aid practitioner understanding. Canton (2011) recommends that involving the offender in the planning process and giving offenders the opportunity to express their view in relation to their offending behaviour is important. This is seen to assist offenders in painting a picture of how they may see the future (Bordin's "goal") and what steps they need to take in order to achieve this (Bordin's "task"). Okimoto, Wenzel and Feather (2009) state that YAOs are more likely to attend interventions if they have contributed and agreed to them, rather than those that have been imposed on them. However, if offenders lack maturity they may also lack the ability or motivation to respond to failure effectively. For example, if a YAO fails to report early on into an order, 
they may continue to fail to report due to anxieties related to missing the first appointment (Marder, 2013), thus impacting on sentence planning and subsequent interventions.

With this in mind, McNeill (2003) highlighted the importance of assessments and subsequent interventions being thoroughly individualised if they are going to be more desistancefocused. Further to this, McNeill (2003) states that to achieve an individualised assessment, probation practitioners, in partnership with the offender, need to map out the differing interfaces between levels of maturity (maturational reform), personal history and current social circumstances (social bonds), and their narratives around change, motivation, views and attitudes (narrative theory). By building meaningful relationships with YAOs it is argued that this may nurture confidence and a belief in change. If a YAO can learn how to relate and trust through the practitioner-offender relationship, this could consequently create a stabilising effect as they construct relational capital to resolve problems in other aspects of their lives.

This paper has outlined some of the many ways in which probation practitioners can carry out desistance and relational focused work with YAOs. Being desistance focused requires thoroughly individualised assessments and sentence plans that have been developed based on how the three areas of desistance (maturational reform, social bonds theory and subjective narratives) interact (McNeill, 2003). Achieving this aim within current probation practice can be difficult to achieve, as there is limited training available and research relating to YAOs is not actively disseminated to frontline staff. Further to this, the concept of maturity is not fully assessed or pursued within the service and this leaves assessments open to greater subjectivity. In addition to this, current standardised assessments tend to see the 'worst in people' and an explicit dialogue with the YAO, focusing on their strengths and motivation to 
change is an area that is barely assessed within OASys. Timeliness targets in relation to the completion of assessments do not allow for a complete appraisal of an offender's past and current situation, which can lead to inaccuracies in developing sentence plans and hinder the desistance process. Through building and safeguarding positive relationships with YAOs, collaborative assessment and planning can increase the knowledge and understanding of a YAO and it is hoped thata bond between the YAO and practitioner is nurtured. It is possible to draw on the knowledge of Bordin's Triad and relational ruptures to shine some light on how to facilitate the process of developing positive relationships between the practitioner and offender. It has been argued that building a positive working relationship with YAOs, will also facilitate other processes within practice, assist in understanding the possibly chaotic lives of the YAO and ultimately support desistance. In order to do this, both the organisation and the practitioner need to take responsibility to fully appreciate and understand the YAO within their social context, recognising diverse needs and focusing upon positives rather than just addressing risks/needs (Faulkner \& Burnett, 2012).

Desistance also requires the accessing of opportunities to change and offering resources to the offender. Employment is strongly linked to promoting desistance, however at present there is a shortage of funding available to particular offender groups, which makes desistance difficult to achieve. At this point, if social bonds are strengthened then an individual is more likely to be in a position to become a 'desister' and begin to explore the notion of adopting a 'non- offending' identity or abandoning the development of an 'offending' identity. It is recognised that the odds are against us when considering the position of the YAO within their life-course, but hope in change and perseverance are essential virtues to encourage practitioners to recognise that success is relative to the position a YAO sits within their lifecourse. A greater acknowledgement of the YAO's position in their life-course and 
understanding that desistance could be a significant challenge needs to embraced through a more tolerant and mindful approach when working with YAOs in the community.

Moving forward, the introduction of a maturity assessment tool is called for in order to aid the practitioner in capturing an accurate picture of the YAO, as they start a community order. Giving practitioners more opportunities to build positive working relationships by relaxing local targets in relation to timeliness, and focusing more on motivation and strengths, could assist practitioners in creating desistance focussed assessments and sentence plans. This is conditional on the practitioner possessing therapeutic virtues, a belief in change and intrinsic motivation to create opportunities for YAOs to become involved in their own rehabilitation, seeking out knowledge that can assist them in this task. This would then lead to more accurate, individually tailored interventions that focus more on what the YAO has to offer going forward, rather than the negatives of the past. Whilst the odds are against practitioners in this venture, the rewards to the offender, victim and community make the investment in YAOs fully justified and whole heartedly embraced.

\section{References}

Allen, R. (2008). Changing public attitudes to crime and punishment: Building confidence in community penalties. Probation Journal, 55(4), 389-400.

Amaro, H., Blake, S., Schwartz, P., \& Flinchbaugh, L. (2001). Developing Theory-Based Substance Abuse Prevention Programs for Young Adolescent Girls. The Journal of Early Adolescence, 21, 256-264. DOI:10.1177/0272431601021003002 
Ansbro, M. (2008). Using attachment theories with offenders. Probation Journal, 55(3): 231244. DOI: $10.1177 / 0264550508092812$

Barrow Cadbury Trust (2005). Lost in Transition. London: Barrow Cadbury Trust. Retrieved from the Transition to Adulthood website: http://www.t2a.org.uk/publications/\#all

Barry, M. (2006). Youth Offending in Transition: The search for social recognition. Oxon: Routledge.

Barry, M. (2007). Listening and Learning: The reciprocal relationship between worker and client. Probation Journal, 54(4), 407-422. DOI 10.1177/0264550507083539

Barry, M. (2012). Young women in transition: from offending to desistance. In F. Lösel, A. Bottoms \& D.P. Farrington (Eds.), Young Adult Offenders Lost in Transition? (p 113-127). Oxon: Routledge.

Bonta, J. and Andrews, D. (2010). Viewing offender assessment and rehabilitation through the lens of the risk-needs-responsivity model. In F. McNeill, P. Raynor and C. Trotter (Eds.), Offender Supervision: New directions in theory, research and practice (p 19-40). Cullompton: Willan.

Bordin, E. (1994). "Theory and research on the therapeutic working alliance". In. O. Horvath \& S. Greenberg, (Eds). The Working Alliance: Theory, Research and Practice. (p 113-137). New York: Wiley. 
Bottoms, A. and Shapland, J. (2011). Steps towards desistance among male young adult recidivists. In S. Farrall, M. Hough, S. Maruna \& R.Sparks (Eds.), Escape Routes: Contemporary Perspectives on Life After Punishment (p 43-80). Oxon: Routledge.

Bottoms, A., Shapland, J., Costello, A., Holmes, D. \& Muir, G. (2004). Towards Desistance: Theoretical Underpinnings for an Empirical Study. The Howard Journal, 43(4), 368-389. Retrieved from: http://www.upf.edu/fdret/_pdf/HowardJnlPDF.pdf

Brodie, E., Cowling, E., Nissen, N., Ellis Paine, A., Jochum, V. \& Warburton, D. (2009). Understanding participation: A literature review. Retrieved from: http://www.pathwaysthroughparticipation.org.uk/wpcontent/uploads/sites/3/2009/09/Pathways-literature-review-final-version.pdf

Burnett, R. \& McNeill, F. (2005). The place of the officer-offender relationship in assisting offenders to desist from crime. Probation Journal, 52(3), 221-242. DOI:

$10.1177 / 0264550505055112$

Bushway, S.D., Piquero, A.R., Broidy, L.M, Cauffman, E. \& Mazerolle, P. (2001). An Empirical Framework for studying desistance as a process. Criminology, 39(2), 491-516. DOI: 10.1111/j.1745-9125.2001.tb00931.x

Canton, R. (2011). Probation: Working with offenders. Oxon: Routledge.

Carlen, P. (2013). Against Rehabilitation: for reparative justice. Criminal Justice Matters, 91(1), 32-33. DOI: 10.1080/09627251.2013.778760 
Castonguay, L., Constantino, M., \& Holtforth, M. (2006). The working alliance: Where are we and where should we go? Psychotherapy: Theory, Research, Practice, Training. 43(3), 271-279. DOI: $10.1037 / 0033-3204.43 .3 .271$

Chiricos, T., Barrick, K., Bales, W., \& Bontrager, S. (2007). The labelling of convicted felons and its consequences on recidivism. Criminology, 549 (3), 547-581.

Day, A., \& Ward, T. (2010). Offender Rehabilitation as a Value-Laden Process. International Journal of Offender Therapy and Comparative Criminology, 54(3), 289-306.

Dunkel, F. \& Pruin, I. (2012). Young adults offenders in juvenile and criminal justice systems in Europe. In F. Lösel, A. Bottoms \& D.P. Farrington (Eds.), Young Adult Offenders Lost in Transition? (p 11-38). Oxon: Routledge.

Eidelson, B. (2013). Treating People as Individuals. Retrieved from: http://papers.ssrn.com/sol3/papers.cfm?abstract_id=2298429

Everall, R., \& Paulson, B. (2002). The Therapeutic Alliance: Adolescent perspectives. Counselling and Psychotherapy Research, 2(2), 78-87.

Faulkner, D. \& Burnett, R. (2012). Where next for Criminal Justice? Bristol: The Policy Press. 
Farrall, S. (2002). Rethinking What Works with Offenders: Probation, Social Context and Desistance from Crime. Cullompton: Willan.

Farrall, S. (2004). Supervision, motivation and social context: what matters most when probationers desist? In G. Mair (Ed.), What Matters in Probation, (p 187-209). Cullompton: Willan.

Farrall, S., Mawby, R.C., \& Worrall, A. (2007). 'Prolific/ Persistent Offenders and

Desistance' in L. Gelsthorpe and R. Morgan (Eds.) The Handbook of Probation, (p 352-380).

Cullompton: Willan.

Farrington, D.P., Loeber, R. \& Howell, J.C. (2012). Young Adult Offenders: The Need for More Effective Legislative Options and Justice Processing. American Society of Criminology, 11 (4), 729-750. DOI: 10.1111/j.1745-9133.2012.00842.x

Farrow \& Hughes (2013). Taking Account of Maturity in Sentencing Young Adults. Retrieved from the Criminal Law and Justice Weekly website:

http://www.criminallawandjustice.co.uk/comment/Taking-Account-Maturity-Sentencing$\underline{\text { Young-Adults }}$

Fitzgibbon, D.W. (2008). Deconstructing Probation: Risk and Developments in Practice. Journal of Social Work Practice: Psychotherapeutic Approaches in Health, Welfare and the Community, 22 (1), 85-101. DOI: 10.1080/02650530701872405 
Gadd, D. \& Farrall, S. (2004). Criminal Careers, Desistance and Subjectivity: Interpreting Men's Narratives of Change. Theoretical Criminology, 8(2), 123-156. DOI:

$10.1177 / 1362480604042241$

Hedderman, C. (2004). The 'Criminogenic' Needs of Women Offenders. In G. McIvor (Eds.), Women Who Offend (p 227-244). London: Jessica Kingsley.

Helyar-Cardwell, V. (2009). Young Adult Manifesto. London: Transition to Adulthood Alliance. Retrieved from: http://www.t2a.org.uk/publications/\#all

Hopkinson, J. \& Rex, S. (2003). Essential Skills in Working with Offenders. In W. H. Chui and M. Nellis (Eds.), Moving Probation Forward Evidence, Arguments and Practice (p 163180). Harlow: Pearson Education Limited.

House of Commons Hansard (2012), House of Commons Written Answer ('Youth Sentencing Policy'), 6 February 2012, Column 20W.

House of Commons Hansard (2012), House of Commons Written Answer ('Crime - Ethnic groups'), 6 February 2012, Column 20W-21W.

Hughes, W. (2012). Promoting offender engagement and compliance in sentence planning: Practitioner and service user perspectives in Hertfordshire. Probation Journal, 59(1), 49-65. 
Kazemian, L. \& Farrington, D. P. (2010). The Developmental Evidence Base: Desistance. In G. J. Towl \& D. A. Crighton (Eds.), Forensic Psychology, (p 133-147). Chichester: Blackwell.

King, S. (2013). Assisted desistance and experiences of probation supervision. Probation Journal, 60(2), 136-151.

Lancaster, E. and Lumb, J. (2006). The assessment of Risk in the National Probation Service of England and Wales, Journal of Social Work, 6 (3), 275-291. DOI: $10.1177 / 1468017306071176$

Laub, J.H. \& Sampson, R.J. (2001). Understanding Desistance from Crime. Crime and Justice, 28 (2001), 1-69.

Laub, J.H. \& Sampson, R.J. (2003). Sharing Beginnings, Divergent Lives: Delinquent Boys to Age 70. Massachusetts: Harvard University Press.

Lewis, S. (2014a). Learning from Success and Failure: Deconstructing the working relationship within Probation practice and exploring its impact, using a collaborative approach. Probation Journal. DOI: 10.1177/0264550514523816

Lewis, S. (2014b). Exploring positive working relationships in light of the aims of Probation, using a collaborative approach. Probation Journal. DOI: 10.1177/0264550514548249 
Lipsey, M. (1995). What do we Learn from 400 Research Studies on the Effectiveness of Treatment with Juvenile Delinquents? In J. McGuire (Eds.), What Works: Reducing Reoffending Guidelines from Research and Practice (p. 63-78). Chichester: John Wiley \& Sons.

Losel, F., Bottoms, A. \& Farrington, D.P. (2012). Introduction. In F. Lösel, A. Bottoms \& D.P. Farrington (Eds.), Young Adult Offenders Lost in Transition? (p.1-10). Oxon: Routledge.

Marder, I. (2013). Restorative Justice for Young Adults: Factoring in Maturity and Facilitating Desistance. Retrieved from: http://www.barrowcadbury.org.uk/wpcontent/uploads/2013/05/m589_untapped.pdf

Maruna, S. (2001). Making Good: How ex-convicts reform and rebuild their lives. Washington DC: American Psychological Association.

Maruna, S., Immarigeon, R. \& LeBel, T.P. (2004). Ex-offender reintegration: theory and practice. In S. Maruna and R. Immarigeon (Eds.) After Crime and Punishment: Pathways to offender reintegration, (p.3-26). Cullompton: Willan.

Maruna, S. \& Roy, K. (2007). Amputation or Reconstruction? Notes on the Concept of “Knifing Off” and Desistance From Crime. Journal of Contemporary Criminal Justice, 23(1), 104-124. DOI: $10.1177 / 1043986206298951$ 
Mason, P. \& Prior, D. (2008). Engaging Young People who Offend. Retrieved from: http://yjbpublications.justice.gov.uk/en-

$\mathrm{gb/Resources/Downloads/Final \% 20EYP \% 20source.pdf}$

Matthews. B., \& Hubbard, D. (2007). The helping alliance in juvenile Probation: The missing element in the "What Works" literature. Journal of Offender Rehabilitation, 45(1-2), 105-122.

McGuire, J. and Priestley, P. (1995). Reviewing 'What Works': Past, Present and Future. In J. McGuire (Eds.), What Works: Reducing Reoffending Guidelines from Research and Practice (pp. 3-34). Chichester: John Wiley \& Sons.

McNeill, F. (2003). Desistance-Focused Probation Practice. In W.H. Chui \& M. Nellis (Eds.), Moving Probation Forward. Evidence, Arguments and Practice. (p.146-162). Essex: Pearson Longman.

McNeill, F. (2006). A desistance paradigm for offender management. Criminology and Criminal Justice, 6 (1), 39-62. DOI: 10.1177/1748895806060666

McNeill, F., Anderson, K., Colvin, S., Overy, K., Sparks, R. and Tett, L. (2011)

'Kunstprojecten en What Works; een stimulans voor desistance?' (Trans. 'Inspiring Desistance? Arts projects and 'what works?') Justitiele verkenningen 37(5) 80-101. Ministry of Justice (MoJ) (2012). Young Adults Offenders. Retrieved from the Ministry of Justice website: http://www.justice.gov.uk/offenders/types-of-offender/young-adult-offenders 
Ministry of Justice (MoJ) (2013). Transforming Rehabilitation; A strategy for reform. London: MoJ.

Nacro (2013). Response to MoJ consultation on transforming management of young adults in custody. Retrieved from: http://www.nacro.org.uk/data/files/consultation-transforming$\underline{\text { management-of-young-adults-1020.pdf }}$

National Offender Management Service (NOMS) (2006). The NOMS Offender Management Model. London: Home Office.

National Offender Management Service (NOMS) (2011). Practice Framework: National Standards for the Management of Offenders: For England and Wales. London: Ministry of Justice.

National Offender Management Service (NOMS) (2012). Sentence Planning. Probation Instruction 21/12. Retrieved from:

http://www.justice.gov.uk/downloads/offenders/psipso/psi-2012\%20/psi-41-2012-sentenceplanning.doc

Offermann, L. \& Rosh, L. (2012, June 13). Building Trust Through Skilful Self-Disclosure. Retrieved from: http://blogs.hbr.org/2012/06/instantaneous-intimacy-skillfu/ 
Okimoto, T., Wenzel, M. \& Feather, N., (2009). Beyond Retribution: Conceptualizing Restorative Justice and Exploring its Determinants. Social Justice Research, 22(1), pp. 156180.

Orsi, M., LaFortune, D., \& Brochu, S. (2010). Care and Control: Working alliance among young adolescents in authoritarian settings. Residential Treatment for Children and Youths, 27(4), 277-303.

Prison Reform Trust (2012). Old Enough To Know Better? A briefing on young adults in the criminal justice system in England and Wales January 2012. Retrieved from:

http://www.prisonreformtrust.org.uk/portals/0/documents/oldenoughtoknowbetter.pdf

Prison Reform Trust (2013). Bromley Briefing Summer 2013. Retrieved from http://www.prisonreformtrust.org.uk/Portals/0/Documents/Prisonthefacts.pdf

Prior, D., Farrow, K., Hughes, N., Kelly, G., Manders, G., White, S. \& Wilkinson, B. (2011). Maturity, young adults and criminal justice: A literature review. Birmingham: University of Birmingham. Retrieved from: http://www.t2a.org.uk/publications/\#all

Reitzel-Jaffe, D. \& Wolfe, D.A. (2001). Predictors of Relationship Abuse Among Young Men. Journal of Interpersonal Violence, 16(2), 99-115. DOI: 10.1177/088626001016002001

Rex, S. (1999). Desistance from Offending: Experiences of Probation. The Howard Journal, 38(4), 366-383. DOI: 10.1111/1468-2311.00141 
Robinson, G. (2005). 'What Works in offender management?' Howard Journal of Criminal Justice, 44(3), 307-318. DOI: 10.1111/j.1468-2311.2005.00374.x

Rogers, C. (1967). On becoming a person: A therapist's view of psychotherapy. London: Constable \& Company.

Safran, J., \& Muran, J. (2003). Negotiating the Therapeutic Alliance: A Relational Treatment Guide. New York: Guildford Press.

Sentencing Council (SC) (2012). Assault Definitive Guideline. Retrieved from: http://sentencingcouncil.judiciary.gov.uk/docs/Assault_definitive_guideline_Crown_Court.pdf

Shapland, J. Bottoms, A. \& Muir, G. (2012). Perceptions of the criminal justice system among young adult desisters. In F. Lösel, A. Bottoms \& D.P. Farrington (Eds.), Young Adult Offenders Lost in Transition? (p.128-145). Oxon: Routledge.

Smith, D. (2004). 'The Uses and Abuses of Positivism'. In G. Mair (Ed.), What Matters in Probation, (p.34-52). Cullompton: Willan.

Sorsby, A., Shapland, J., Farrall, S., McNeill, F., Priede, C., \& Robinson, G. (2013). Probation staff views of the Skills for Effective Engagement Development (SEED) Pilot. Retrieved from: https://www.gov.uk/government/uploads/system/uploads/attachment_data/file/224308/probat $\underline{\text { ion-views-seed-pilot.pdf }}$ 
Transition to Adulthood (T2A) Alliance (2012). Pathways from Crime: 10 steps to a more effective approach for young adults throughout the criminal justice process. London: T2A Alliance. Retrieved from: http://www.t2a.org.uk/publications/\#all

Transition to Adulthood (T2A) Alliance (2013). Taking Account of Maturity A Guide for Probation Practitioner., London: T2A Alliance.

Trotter, C. (2009). Pro-Social Modelling. European Journal of Probation. 1(2), 142-152.

Ward, T. (2010). The Good Lives Model of offender rehabilitation: basic assumptions, aetiological commitments, and practices implications. In F. McNeill, P. Raynor and C. Trotter (Eds.), Offender Supervision: New directions in theory, research and practice (p.4165). Cullompton: Willan.

Weaver, B. \& McNeill, F. (2007a). Desistance. In R. Canton and D. Hancock (Eds.), Dictionary of Probation and Offender Management (p.90-92). Cullompton: Willan.

Weaver, B. \& McNeill, F. (2007b). Giving Up Crime: Directions for Policy. Retrieved from the SCCJR website: http://www.sccjr.ac.uk/publications/giving-up-crime-directions-forpolicyl

Weaver, B. \& McNeill (2010). Travelling hopefully: Desistance research and probation practice. In J. Brayford, F Crowe \& J. Deering (Eds.), What else works? Creative Work with Offenders, (p.36-60). Cullompton: Willan. 
Wright, J.P., Carter, D.E., \& Cullen, F.T. (2005). A life-course analysis of military service in Vietnam. Journal of Research in Crime and Deliquency, 42, 55-83. DOI:

$10.1177 / 0022427804270436$ 